\title{
Effect of organic amendments on microbial biomass of a tropical soil treated with some herbicides
}

\author{
A.D.V. AYANSINA ${ }^{1^{*}}$ and B.A. OSO ${ }^{2}$ \\ ${ }^{1}$ Department of Biological Sciences, Bowen University, P.M.B. 284, Iwo, Osun State, Nigeria. \\ ${ }^{2}$ Department of Botany and Microbiology, University of Ibadan, Ibadan, Nigeria. \\ Corresponding author, E-mail-ayandvt@yahoo.com
}

\begin{abstract}
Studies were carried out on the impact of organic amendments on microflora of soils treated with 2,4dichlorophenoxy-acetic acid, atrazine, atrazine + metolachlor and paraquat herbicides applied at one and half doses of the recommended rates. Poultry manure- $0.05 \%$, urea- $0.1 \mathrm{M}$ and glucose $-0.1 \mathrm{M}$ of herbicide-treated soils resulted in significant $(\mathrm{P}<0.05)$ increases in microbial biomass and highest significant increases in microbial counts for all the treatments, with maximum counts of $12.1 \times 10^{7} \mathrm{cfu} / \mathrm{ml}$ for $2,4-\mathrm{D}, 10.2 \times 10^{7} \mathrm{cfu} / \mathrm{ml}$ for atrazine, $10.4 \times 10^{7} \mathrm{cfu} / \mathrm{ml}$ for atrazine + metolachlor and paraquat, followed by urea amendment, while glucose gave the lowest increase in microbial population $(\mathrm{P}<0.05)$. Bacillus spp. $(39.1 \%)$, Pseudomonas spp (30.4\%), Flavobacterium spp. (8.7\%), Actinomycetes (5.8\%) and Proteus spp. (4.3\%) were isolated from control soils; while Bacillus (42.3\%) and Pseudomonas (50.9\%) species were most frequently isolated from herbicide treated soils. Introduction of organic amendments therefore, significantly $(\mathrm{P}<0.05)$ resulted in increases in microbial biomass with greater probability for pesticide degradation.
\end{abstract}

(C) 2008 International Formulae Group. All rights reserved.

Keywords: Amendments, bacteria, biomass, herbicides, microflora

\section{INTRODUCTION}

It has been estimated that over 500,000 tonnes of active ingredients (ai) of pesticides are applied in the third world countries annually (Brader, 1987). In such places pesticide use is still growing rapidly and compounds that have long been banned or restricted on health grounds in the developed countries are still used in many third world countries (Repetto and Boliga, 1996). Moreover, pesticide regulations are weak and local farmers lack the training and equipment to handle pesticides safely.

The cycling of nutrients in soils is largely governed by the soil microbial biomass and it is the supply of energy principally in the form of fixed carbon that drives this function (Wardle, 1992; Witter and Martenssion, 1993). Biodegradation of organic compounds is often slow because one or more inorganic nutrients needed for microbial growth are in low concentrations in the natural environment (Lewis et al. 1986; Swindoll et al. 1988; Convey and Wetzel, 1992). The addition of nitrogen and phosphorous may therefore enhance biodegradation of organic compounds (Pritchard and Coasta, 1991) but it can also have no effect or decrease the rate of biodegradation (Swindoll, 1988).

Heterotrophic microbial activity appears to be severely limited in most soils by a lack of easily available carbon substrate. The addition of sugars leads to a marked increase in soil microbial activity, which under aerobic conditions can be most readily observed as an increase in soil respiratory activity (Falih and Wainwright, 1996).

The activity of the microbial biomass is commonly used to characterize the microbiological status of a soil (Nannipieri et al., 1990) and to determine the effects of 
cultivation (Anderson and Domsch, 1993) or contamination (Chander and Brookes, 1993) on soil microorganisms. Total organic carbon and $\mathrm{pH}$ have important effects on the microbial biomass level (Gehlen and Schroder, 1989). Also, the structure and distribution of carbon in soil affect biological activity (Vaughan and Malcolm, 1985). Soil organic residues from plants, dead organisms and fertilizers are decomposed by microorganisms and transformed to humic compounds. The easily available organic compounds (proteins, polysaccharides etc) are preferred as energy sources by microorganisms (Burns and Martin, 1986). In contrast, the positive effects of farmyard manures or cow dung in increasing nutrient supply, $\mathrm{pH}$, organic carbon and cation exchange capacity of savanna soils has been reported (Heathcote, 1970).

Manure-based fertilization or organic farming systems necessarily involves the addition of large quantities of carbon in addition to the nutrient elements with which the crops are being fertilized. Carbon additions of virtually any form to arable soils often stimulate microbial biomass size (Fauci and Dick 1994; Joegensen et al., 1995) and activity (Jackson and Elliot, 1986; Doran et al., 1987).

The application of organic manure (e.g. farmyard manure) usually increases the soil microbial biomass (Sakamoto and Oba, 1991). Introduction of organic amendments to soils have been reported to significantly enhance global farming systems (Smaling and Dixon, 2006). Farmyard manure is commonly used as organic manure in the tropics (Ghosal and Singh, 1995). It is a composted mixture of cattle dung, the bedding used in the stable, and the remnants of straw and plant stalks fed to cattle.

This study was carried out to show the impact of organic amendments on the microbial biomass of a soil treated with herbicides in a tropical ecosystem and to determine the effect of applied herbicides on bacterial species in treated soil.

\section{MATERIALS AND METHODS}

Soil sample treatment with test herbicides

Top soil sample (0-20 cm deep) was collected from a maize farm in Ibadan, Nigeria. The soil sample was sieved through a
$2.00 \mathrm{~mm}$ width mesh to remove stones and plant debris. One kilogramme soil sample was treated with one and half times (x 1.5ai) of recommended doses of each herbicide studied. Generally, the use of $\mathrm{x} 1.5$ recommended herbicide rates was taken to correspond approximately with the local peasant farmer's practice (Mathews, 1992).

Four herbicides were used and these included 2,4-D, atrazine (At), atrazine + metolachlor (AtM) and paraquat $(\mathrm{Pq})$. One kilogramme of the soil samples were first separately treated with $\mathrm{x} 1.5$ doses (ai) of each of the herbicides, while another set treated with distilled water served as control.

\section{Application of soil amendments to herbicide-treated soil samples}

The following organic soil amendments (in $100 \mathrm{ml}$ solutions) were applied to the herbicide treated soils: glucose $(0.1 \mathrm{M} / \mathrm{kg})$, urea $(0.1 \mathrm{M} / \mathrm{kg})$ and poultry manure $(0.05 \% / \mathrm{kg})$. The treatments were replicated, kept in plastic bowls in the laboratory. The experimental design and sampling method were completely randomized. Soil samples were taken for analysis on a weekly basis for eight weeks.

\section{Effect of treatment on bacterial flora of the soil samples}

Plate count agar (oxiod) was used to carry out the analysis of aerobic and facultatively anaerobic bacteria. The usual pour plate method was used. Bacteria isolation and characterization steps included; Gram's staining, endospore staining, oxidase test, catalase test, citrate utilization test, MR-VP test and sugar fermentation test.

\section{Statistical analysis}

Data generated were subjected to analysis of variance (ANOVA), while Duncan's Multiple Range Test and Least Significance Difference (LSD) at $\mathrm{P}<0.05$ were used for statistical test of significance.

\section{RESULTS AND DISCUSSION}

The effect of herbicide treatments and organic amendments on mean viable bacterial counts are presented in figures 1, 2, 3 and 4. Soil samples treated with 2, 4-D (no amendments) resulted in initial increase in bacterial counts attaining a maximum by $3^{\text {rd }}$ and $4^{\text {th }}$ week $\left(4.5 \times 10^{7} \mathrm{cfu} / \mathrm{ml}\right)$. This initial 
rise was followed by a general decline in the subsequent weeks. Soil amendment with manure resulted in the highest impact on bacterial counts $\left(12.1 \times 10^{7} \mathrm{cfu} / \mathrm{ml}\right.$ at week 3$)$; followed by urea amended soil $\left(9.6 \times 10^{7}\right.$ $\mathrm{cfu} / \mathrm{ml}$ at week 3 ) and glucose amended soil $\left(8.6 \times 10^{7} \mathrm{cfu} / \mathrm{ml}\right.$ at week 3$)$.

In atrazine-treated soils (no amendments) maximum bacterial counts were observed at weeks 4 and $5\left(4.5 \times 10^{7} \mathrm{cfu} / \mathrm{ml}\right)$. Highest significant increase in bacterial counts $\left(10.2 \times 10^{7} \mathrm{cfu} / \mathrm{ml}\right)$ was obtained in manure amended soil $(\mathrm{P}<0.05)$ followed by urea amended soils $\left(9.2 \times 10^{7} \mathrm{cfu} / \mathrm{ml}\right.$ at week 4$)$ and glucose amended soils $\left(8.2 \times 10^{7} \mathrm{cfu} / \mathrm{ml}\right.$ at week 4). A similar pattern of bacterial counts was observed in atrazine + metolachlortreated soils. Maximum bacterial counts were recorded at week $3\left(10.4 \times 10^{7} \mathrm{cfu} / \mathrm{ml}\right)$ in manure amended treatment.

A slightly different bacterial growth pattern was observed in soil treated with paraquat. Soil amendment with urea significantly increased bacterial counts (10.4 $\mathrm{x} 10^{7} \mathrm{cfu} / \mathrm{ml}$ at week 4 ), followed by manuretreated soils $\left(9.8 \times 10^{7} \mathrm{cfu} / \mathrm{ml}\right.$ at week 4$)$ and glucose-treated soils $\left(7.8 \times 10^{7} \mathrm{cfu} / \mathrm{ml}\right.$ at week 4).

An initial general rise in microbial counts reaching a maximum at weeks 3 and 4 was observed. It has been shown that there is a general increase in bacterial and actinomycetes counts attaining a peak at 3 weeks after herbicide treatment of soil (Taiwo and Oso, 1997; Ayansina and Oso, 2006). The initial rise in microbial counts could be due to the fact that the soil microflora was able to temporarily mineralize and use the herbicides as energy sources (Kunc et al., 1985).

Results obtained from this study has shown that introduction of organic amendments to herbicide-treated soils would increase the soil microbial status. An increase in microbial counts is indicative of high probability of herbicide degradation (Moorman et al., 2001). The application of organic amendments resulted in the stimulation of herbicide degradation by enrichment of selected herbicide-degrading microorganisms or a modification of both rates and pathways of herbicide degradation (Houot et al., 1998). It is well established that application of organic resources enhances crop production at the same time serving as sources of nutrients for microorganisms ( $\mathrm{Hu}$ et al., 2006; Vanlauwe and Giller, 2006). Results from this study corroborated Autoun et al. (2003) that application of liquid pig manure significantly enhanced the rate of atrazine mineralization in a maize-cultivated soil.

Increases in microbial counts in manure-treated soils could be attributed to two reasons; firstly, the organic manure carries some microorganisms that can add to the microbial load of the samples and secondly, the manure itself is a rich source of organic matter that supports the growth of microorganisms (Ritz et al., 1997). Therefore, soil with high organic matter tends to adsorb pesticides (Akobundu, 1987). Binding of herbicides to organic matter in soils also reduces the amount of materials available to interact with the biomass and as the amount of available material decreases so does its relative toxicity (Bollag, 1990).

Table 1 shows the major bacterial isolates from the control soil and the frequency of their occurrence. A total of 138 bacterial isolates were obtained and identified. These included: Bacillus spp (39.1\%), Pseudomonas spp. (30.4\%), Flavobacterium spp. (8.7\%), Proteus spp. (4.3\%) and Actinomycetes $(5.8 \%)$.

Table 2 shows the major bacterial isolates from herbicide-treated soils and the frequency of occurrence. Bacillus spp. and Pseudomonas spp. were the most frequently encountered bacteria. It was observed that Proteus spp. and Flavobacterium spp, were eliminated from all the herbicide-treated soils, while Actinomycetes was only isolated from the paraquat-treated soils. Pseudomonas spp. has been widely reported in pesticide-treated soil (Behki and Khan 1986; Boyle 1989; Taiwo and Oso, 1997; Mueller et al., 1998; Ayansina and Oso, 2006). The occurrence of Bacillus spp in pesticide-treated soil has also been reported (Bollag, 1990; Bollag and Liu, 1991 Taiwo and Oso, 1997). While some other bacterial species were eliminated as a result of pesticide treatments, those that survived were able to do so as result of acclimatization of the microbial population with enhanced ability to transform applied pesticides (Spain and van Veld, 1983; Bollag, 1990). 
Table 1: Bacteria isolated from untreated control soil.

\begin{tabular}{lcc}
\hline Bacterial Isolate & Number & Percentage \\
\hline Bacillus spp. & 54 & 39.1 \\
Pseudomonas spp. & 42 & 30.4 \\
Flavobacterium spp. & 12 & 8.7 \\
Actinomycetes & 8 & 5.8 \\
Proteus sppp. & 6 & 4.3 \\
Unidentified & 16 & 11.6 \\
\hline Total & $\mathbf{1 3 8}$ & \\
\hline
\end{tabular}

Table 2: Bacteria isolated from herbicide-treated soils.

\begin{tabular}{ccccc}
\hline 2,4-D & Atrazine & Atrazine + Metolachlor & Paraquat & Mean \% \\
\hline B. spp. 45.8\% & B. spp. 42.3\% & B. spp. 50\% & B. spp. $38.9 \%$ & 42.3 \\
P. spp. 54.2\% & P. spp. 57.7\% & P. spp. $42 \%$ & P. spp. $50 \%$ & 50.9 \\
& & CR $8 \%$ & Acti. $11 \%$. & 6.8
\end{tabular}

\begin{tabular}{cccc}
\hline $\mathrm{TI}=24$ & $\mathrm{TI}=26$ & $\mathrm{TI}=24$ & $\mathrm{GT}=92$ \\
\hline B. spp. = Bacillus spp.; P. spp. $=$ Pseudomonas spp.; $\mathrm{CR}=$ Clustered rods; Acti. = Actinomycetes; & \\
TI = Total isolates; GT = Grand total. &
\end{tabular}

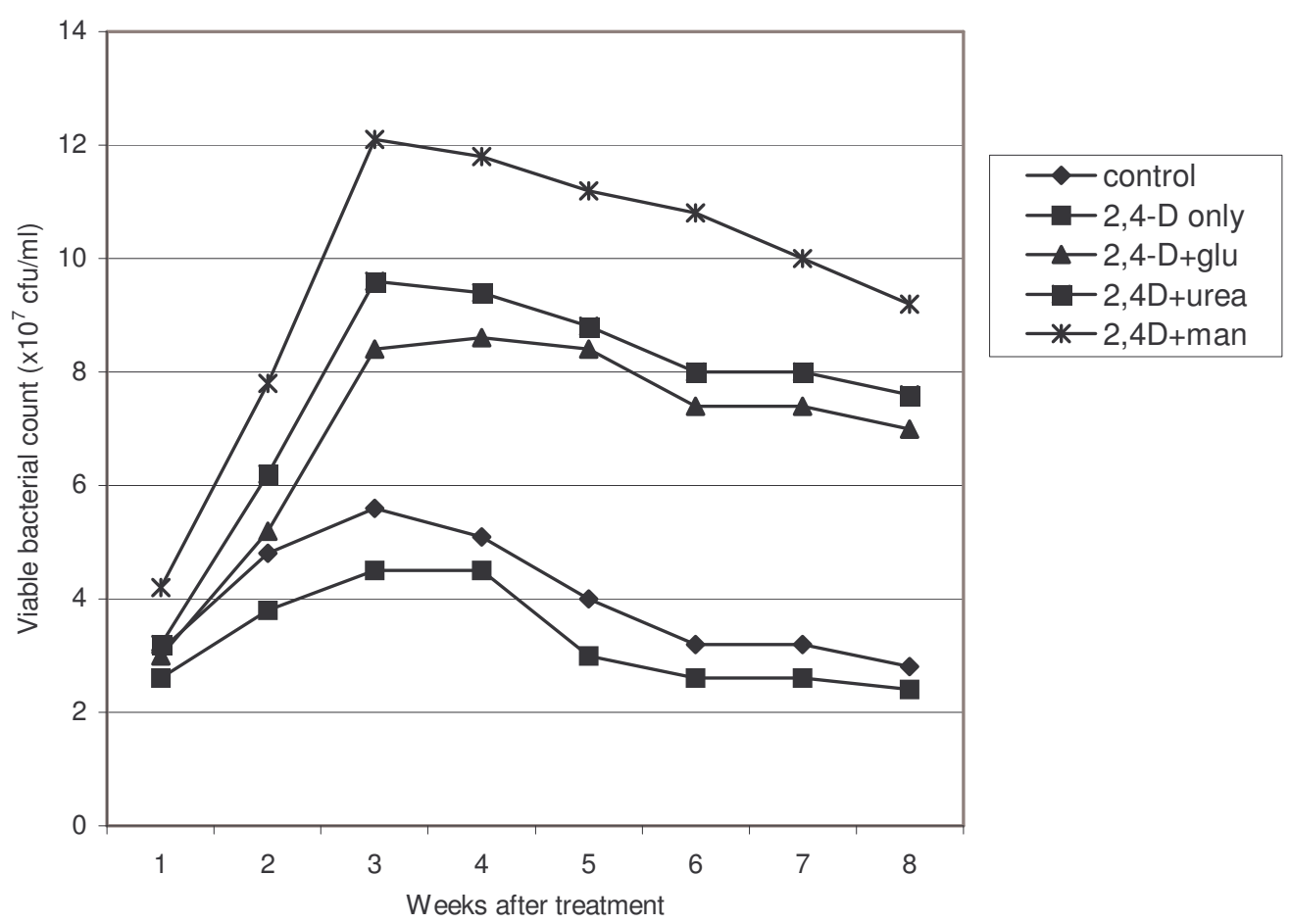

Figure 1: Effect of organic amendments on mean viable bacterial counts in 2,4-D-treated soil at $\mathrm{x} 1.5$ recommended rate. 


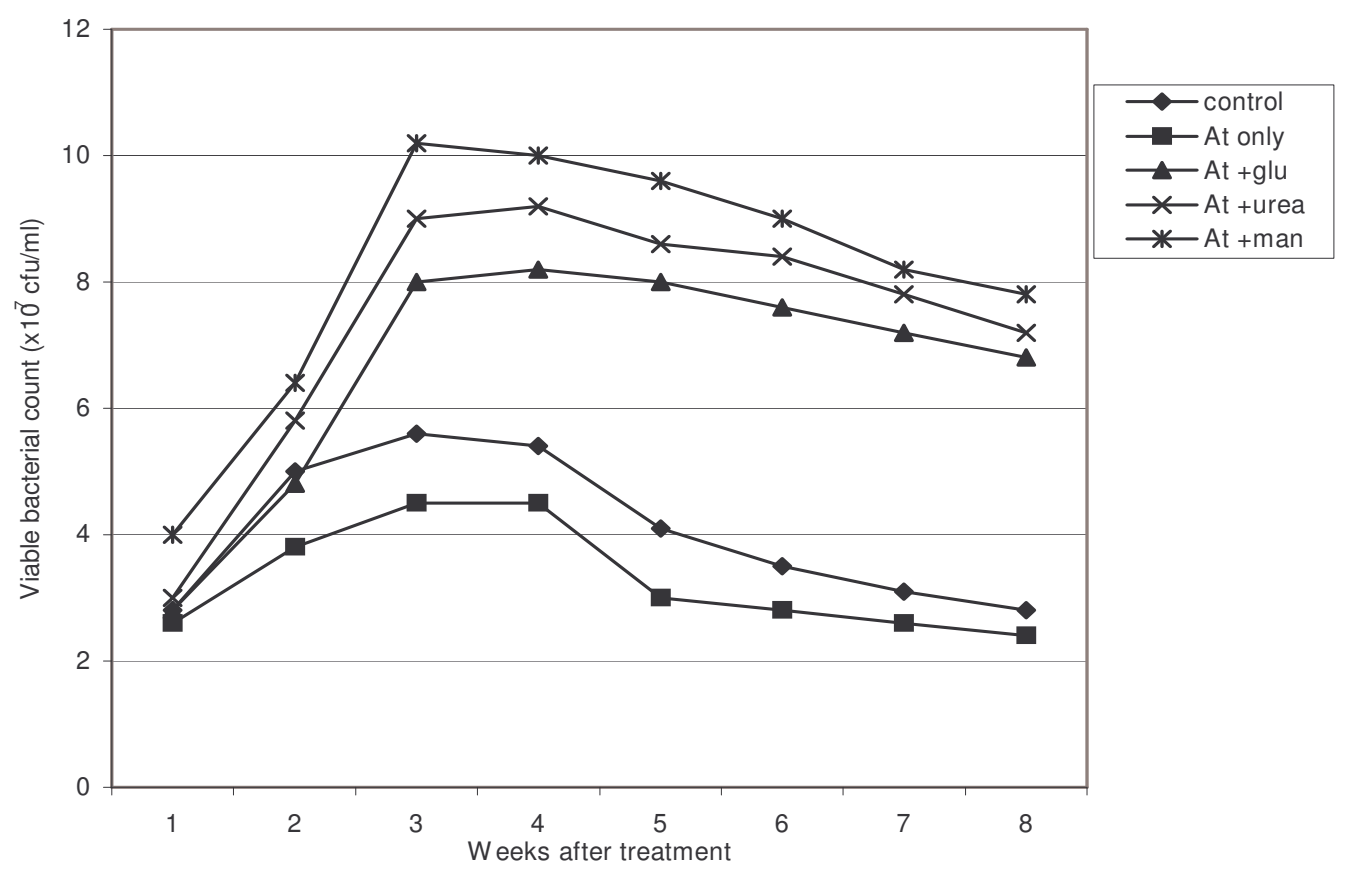

Figure 2: Effect of organic amendments on mean viable bacterial counts in atrazine-treated soil at $\mathrm{x} 1.5$ recommended rate.

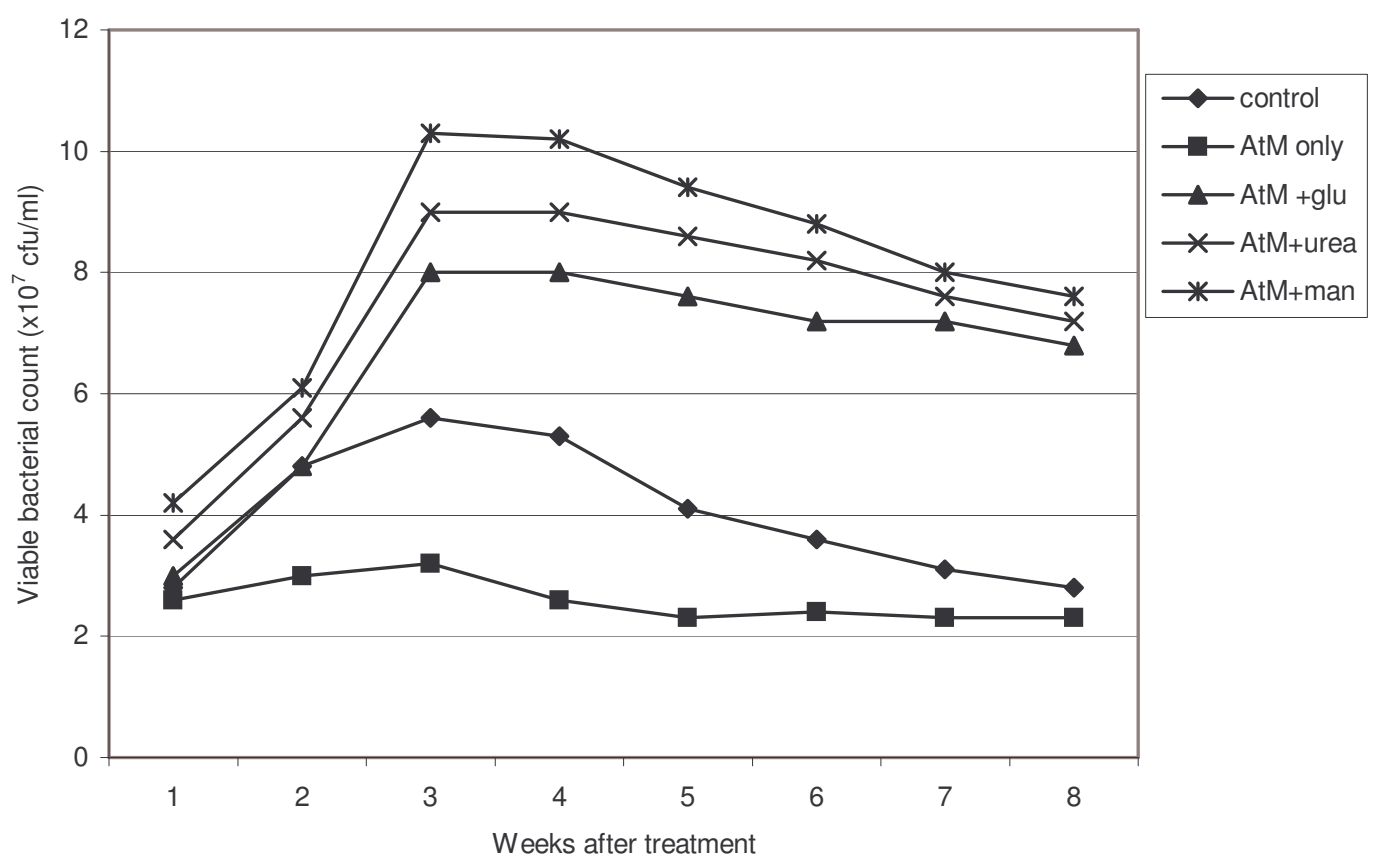

Figure 3: Effect of organic amendments on mean viable bacterial counts in atrazine + metolachlortreated soil at $x 1.5$ recommended rate. 


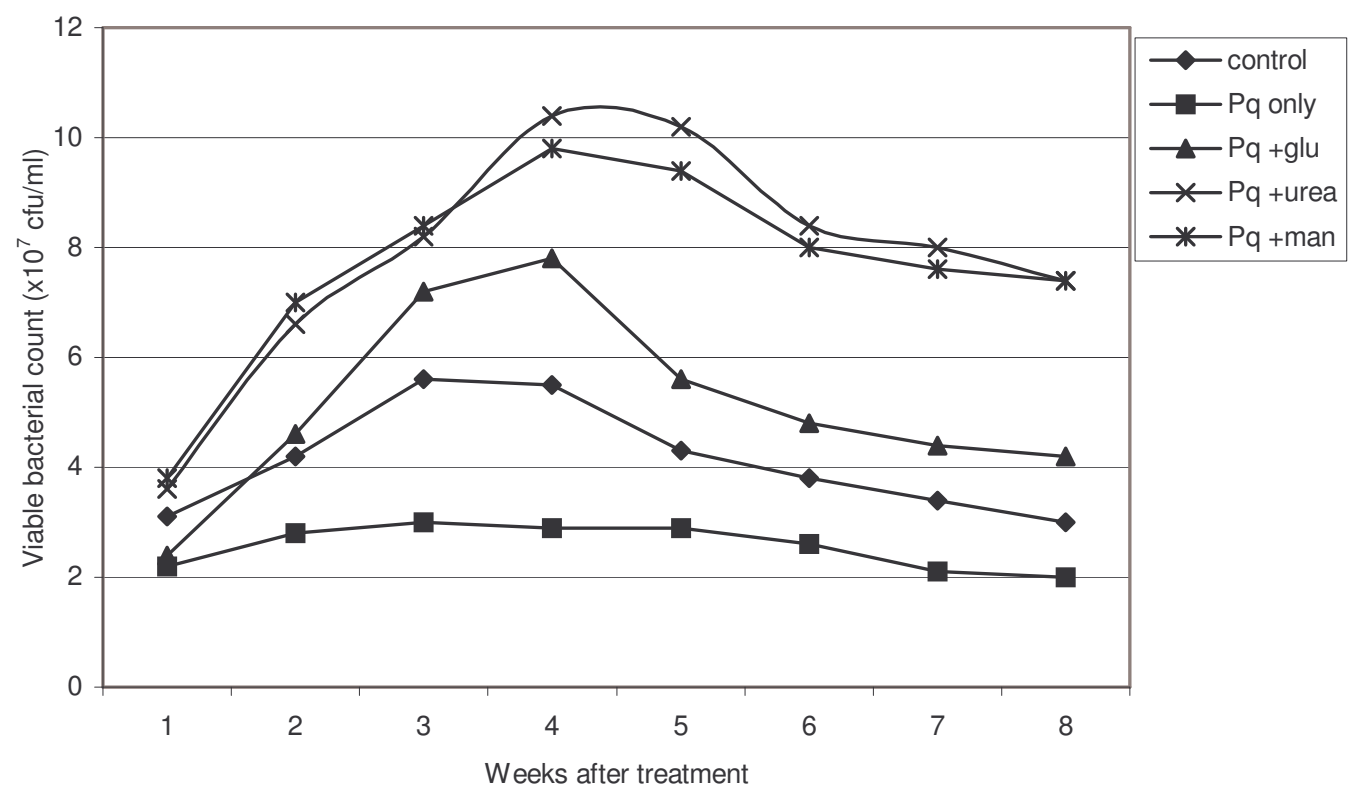

Figure 4: Effect of organic amendments on mean viable bacterial counts in paraquat-treated soil at $\mathrm{x} 1.5$ recommended rate.

\section{ACKNOWLEDGEMENTS}

We appreciate Mr Donatus Esimekhuai of the Dept. of Botany and Microbiology, University of Ibadan, for technical assistance.

\section{REFERENCES}

Akobundu IO. 1987. Weed Science in the Tropics: Principles and Practices. Wiley-Interscience Publ.; 179-205.

Anderson TH, Domsch WN. 1993. The metabolic quotient for $\mathrm{CO}_{2}$ as a specific activity parameter to assess the effects of environmental conditions such $\mathrm{pH}$ on the microbial biomass of forest soils. Soil Biol. Biochem., 25: 393-395.

Antoun H, Bigwaneza PC, Fortin J, Ndayegamiye A, Cote D. 2003. Effect of long-term liquid pig manure application on atrazine mineralization in a soil cultivated with maize. Biol. Fertil. Soils, 38: 191-199.

Ayansina ADV, Oso BA. 2006. Effect of two commonly used herbicides on soil microflora at two different concentrations. African Journal of Biotechnology, 5(2): 129-132.

Behki RM, Khan SU. 1986. Degradation of atrazine by Pseudomonas: N-
Dealkylation and Dehalogination of atrazine and its metabolites. J. Agric. Food Chem., 34: 746-749.

Bollag JM. 1990. Biotransformation of the Herbicide Metolachlor. Devt. Industrial Microbiol., 31: 75-80.

Bollag JM, Liu S. 1991. Microbial transformation of the herbicide Metolachlor. In Diversity of Environmental Biogeochemistry. Vol. 6. Elsevier Science Publ.: Amsterdam; 89-96.

Boyle M. 1989. The environmental microbiology of chlorinated aromatic decomposition - A review. J. Environ Qual., 18: 395-402.

Brader L. 1987. Aspects of pesticide use in developing countries. In Moglichkeiten Grenzen und Alternativen des PflanzenSchutzmitteleinsatzas in Entwicklungs Landen. Bericht der Tagung Vom 9-11 inder ZEL in feldating; 36-44.

Burns RG, Martin JP. 1986. Biodegradation of organic residues in soil. In Microflora and Fauna Interactions in Natural and Agro-ecosystems, Michell MJ, Nakas JP (eds). Nijhoff and Junk Publ.: Dordrecht; 137-202. 
Chander K, Brookes PC. 1993. Residual effects of Zink, Copper and Nickel in sewage sludge on microbial biomass in a sandy loam soil. Soil Biol. Biochem., 25:1231-1239.

Convey MF, Wetzel RG. 1992. Effects of nutrient on specific growth rate of bacterioplankton in oligotrophic lake water cultures. Appl. Environ. Microbiol., 58:150-156.

Doran JW, Fraser DG, Culik MN, Liebhardt WC. 1987. Influence of alternative and conventional agricultural management on soil microbial processes and nitrogen availability. Am. J. Altern. Agric., 2: 99106.

Falih AMK, Wainwright M. 1996. Microbial and enzyme activity in soils amended with a natural source of easily available carbon. Biol. Fertil. Soils, 21:177-183.

Fauci MF, Dick RP. 1994. Plant response to organic amendments and decreasing inorganic nitrogen rates in soils from a long-term experiment. Soil Sci. Soc. Arn. J., 58: 134-138.

Gehlen P, Schroder D. 1989. Bedentung von $\mathrm{pH}$ - wert C-Gehalt Kuitun, substra und Jahreseifuss Fur bodenmicrobiologi-sche Eigenschaften in einheitlich genutzten Ackerboden. VOLUFA Schriften, 30: 467-472.

Ghosa N, Singh KP. 1995. Effects of farmyard manure and inorganic fertilizer on the dynamics of soil microbial biomass in a tropical dryland agroecosyterm. Biol. Fertil. Soils, 19: 231-238.

Heathcote RG. 1970. Soil fertility under continuous cultivation in Northern Nigeria: The role of organic manure. Expt. Agriculture, 6: 229-237.

Houot S, Barriuso E, Bergheaud V. 1998. Modification of atrazine degradation pathways in a loamy soil after addition of organic amendments. Soil Biol. Biochem., 30: $2147-2157$.

Hu S, Tu C, Louws FJ, Creamer NG, Mueller JP. 2006. Responses of soil microbial biomass and $\mathrm{N}$ availability to transition strategies-from convetional to organic farming systems. Agric Ecosystems and Environs., 113: 206-215.

Jackson MD, Elliot LF. 1986. Carbon and its transformations during wheat straw decomposition. Soil Biol. Biochem., 18: 15-22.

Joergensen, RG, Schmaedeke, F, Windhorst, $\mathrm{K}$ and Meyer, B 1995. Biomass and activity of microorganisms in a fuel oil contaminated soil. Soil Biol. Biochem., 27: 1137-1143.

Kunc F, Tichy P, Vancura V. 1985. 2,4dichlorophexoxy-acetic acid in the soil: mineralization and changes in the counts of bacteria decomposers. Versailles Ed. INRA Publ. (Les Colloques de I'INRA, No. 31).

Lewis DL, Kollig HP, Hudson RE. 1986. Nutrient limitation and adaptation of microbial population to chemical transformations. Appl. Environ. Microbiol., 51: 598-603.

Matthews GA. 1992. Pesticide Application Methods (2nd ed). Longman Scientific and Technical, Longman Group Esses: UK.

Moorman JB, Cowan JK, Arthur EL, Coats JR. 2001. Organic amendments to enhance herbicide degradation in contaminated soils. Biol. Fertil. Soil, 33: 541-545.

Mueller R, Wischnak C, Loffler FE, Urbance JW. 1998. Pseudomonas sp. strain 273: an aerobic dichloroalkane-degrading bacterium. Appl. Environ. Microbiol., 64: 3507-3511.

Nannipieri P, Grego S, Ceccanti B. 1990. Ecological significance of the biological activity in soil. Soil Biochem., 6: 293355.

Pritchard PH, Coasta CF. 1991. EPA's Alaska oil spill bioremediation project. Environ. Sci. Technol., 25: 372-379.

Repetto R, Boliga SS. 1996. Pesticide and the immune system: the public health risk. World Resource Institute.

Ritz K, Wheatly RE, Griffiths BS. 1997. Effects of animal manure application and crop plants upon size and activity of soil microbial biomass under organically grown spring barley. Biol. Fertil. Soils, 24: 372-377.

Sakamoto K, Oba Y. 1991. Relationship between the amount of organic material applied and soil biomass content. Soil Sci. Plant Nutrition, 37: 387-397.

Spain JC, Van Veld PA. 1983. Adaptation of natural microbial population to 
degradation of xenobiotic compounds: effects of concentration, exposure time, inoculum and chemical structures. Appl. Environ. Microbiol., 45: 428-435.

Swindoll CM, Aelion CM, Pfaender FK. 1988. Influence of inorganic and organic nutrients on aerobic biodegradation and on the adaptation response of surface microbial communities. Appl. Environ. Microbiol., 54: 212-217.

Smaling EMA, Dixon J. 2006. Adding soil fertility dimension to the global farming systems approach, with cases from Africa. Agric. Ecosystems \& Environs., 116: $15-26$.

Taiwo LB, Oso BA. 1997. The Influence of some pesticides on soil microbial flora in relation to changes in nutrient level, rock phosphate solubilization and P-release under laboratory conditions. Agric. Ecosystem \& Environ., 65: 59-68.

Vanlauwe B, Giller KE. 2006. Popular myths around soil fertility management in subsaharan Africa. Agric Ecosystems and Environs., 116: 34-46.

Vaughan D, Malcolm RE. 1985. Soil Organic Matter and Biological Activity. Nijhoff \& Junk Publ.: Dordrecht.

Wardle DA. 1992. A comparative assessment of factors which influence microbial biomass carbon and nitrogen levels in soil. Biol. Rev., 67: 321-358.

Witter E, Martenssion AM. 1993. Size of the solid microbial biomass in a long-term field experiment as affected by different $\mathrm{N}$-fertilization and organic manure. Soil Biol. Biochem., 25: 659-669. 